\title{
Nowa kompetencja przewodniczącego rady gminy do wydawania poleceń pracownikom urzędu gminy na tle uprawnień wójta
}

New competence of the chairman of the municipal council to give instructions to the employees of the municipal office regarding the powers of the mayor

\section{Wprowadzenie}

Nowelizacja ustawy z dnia 8 marca 1990 r. o samorządzie gminnym (tekst jedn. Dz.U. 2020, poz. 713 z późn. zm; dalej: u.s.g.), dokonana na mocy ustawy z dnia 11 stycznia 2018 r. o zmianie niektórych ustaw w celu zwiększenia udziału obywateli w procesie wybierania, funkcjonowania i kontrolowania niektórych organów publicznych (Dz.U., poz. 130; dalej: ustawa zmieniająca u.s.g.), w istotny sposób zwiększyła indywidualne uprawnienia kontrolne radnych oraz całej rady jako organu stanowiącego i kontrolnego w gminie, w tym w szczególności wzmocniła również pozycję przewodniczącego rady gminy poprzez przyznane mu indywidualne kompetencje. Wyrazem powyższego jest dodanie do u.s.g. art. 21a. Przewodniczący rady gminy został bowiem wyposażony przez ustawodawcę, w związku z wykonywaniem swoich obowiązków, w możliwość wydawania poleceń służbowych pracownikom urzędu gminy, którzy wykonują zadania organizacyjne, prawne oraz inne zadania związane z funkcjonowaniem rady gminy, komisji i radnych, w tym zakresie przewodniczący rady gminy wykonuje wobec rzeczonej grupy pracowników uprawnienia zwierzchnika służbowego. $\mathrm{Z}$ perspektywy kilku lat funkcjonowania omawianej regulacji warto pokusić się o dokonanie oceny przedmiotowej zmiany ustawodawczej oraz wskazania wpływu, jaki wywarła w praktyce na funkcjonowanie jednostek samorządu terytorialnego. 


\section{Wzmocnienie pozycji prawnej przewodniczącego rady gminy}

Gmina zgodnie z art. 164 ust. 1 Konstytucji RP z dnia 2 kwietnia 1997 r. (Dz.U. 1997, nr 78, poz. 483) jest podstawową jednostką samorządu terytorialnego, która w oparciu o przepis art. 2 ust. $1 \mathrm{w}$ zW. $\mathrm{z}$ art. 7 u.s.g. realizuje istotną część zadań publicznych o znaczeniu lokalnym, związanych z zaspokajaniem bieżących, codziennych potrzeb członków lokalnej wspólnoty samorządowej. Aby rzetelnie realizować zadania własne, niezbędne jest sprawne i efektywne funkcjonowanie organów samorządowych w gminie, czyli rady gminy, a także wójta (burmistrza, prezydenta miasta). Ustawa zasadnicza w art. 169 ust. 1 stanowi, że gmina wykonuje swoje zadania za pośrednictwem organów stanowiących i wykonawczych. Przedmiotowa norma konstytucyjna znalazła swoje rozwinięcie w art. 1la ust. 1 u.s.g., który wprowadza katalog zamknięty organów gminy. Rozszerzenie przedmiotowego katalogu o organy pomocnicze organów gminy, np. komisje lub inne struktury, takie jak w szczególności prezydium rady, zespoły, konwenty, nie znajduje uzasadnienia prawnego (Grudek, 2008, s. 76). Zgodnie z ugruntowanymi poglądami judykatury modyfikowanie tego katalogu jest niedopuszczalne, bowiem normy określające strukturę organizacyjną organów gminy oraz ich kompetencje i tryb obsadzania stanowisk mają charakter ius cogens, a do ich zmiany może dojść jedynie w wyniku wyraźnego upoważnienia zawartego w ustawie, a nie na mocy norm aktów podustawowych (Augustyniak, 2020, s. 443). Szczególnie rada gminy odgrywa w przedmiotowym zakresie ważką rolę, która koresponduje $\mathrm{z}$ charakterem tego organu jako organu stanowiąco-kontrolnego, a także jego wewnętrzną strukturą jako organu kolegialnego. Rada gminy, jak każdy organ zbiorowy, musi mieć swego przewodniczącego i obraduje pod jego kierownictwem. Wybór przewodniczącego jest zatem ustawowym obowiązkiem rady gminy.

Nowelizacja u.s.g. dokonana ustawą zmieniającą u.s.g. z dnia 11 stycznia 2018 r. jest odpowiedzią ustawodawcy na pojawiające się postulaty potrzeby wzmocnienia pozycji prawnej organu stanowiącego i kontrolnego w gminie. Ustawą zmieniającą u.s.g. dokonano kilku istotnych zmian zmierzających, zgodnie z intencją prawodawcy, do zwiększenia uprawnień rady gminy oraz radnych, a także wzmocnienia ich wpływu na działalność organu wykonawczego (Budzisz, 2019, s. 102). Szczególnie dążenia te urzeczywistniły się poprzez wyposażenie przewodniczącego rady gminy w niespotykane dotąd kompetencje.

Jednym z przejawów dążenia do próby umocnienia pozycji rady gminy jest wprowadzenie uprawnienia do wydawania poleceń służbowych pracownikom urzędu przez przewodniczącego rady gminy. Od obecnej kadencji 2018-2023 
przewodniczący rady gminy zyskał bowiem nowe kompetencje dotyczące wydawania poleceń służbowych pracownikom urzędu gminy wykonującym zadania organizacyjne, prawne oraz inne zadania związane z funkcjonowaniem rady gminy, komisji i radnych. Formułowane w oparciu o art. 2la u.s.g. polecenia służbowe winny pozostawać $\mathrm{w}$ obszarze związanym $\mathrm{z}$ realizacją obowiązków przewodniczącego rady gminy, gdyż tylko w tym zakresie posiada on uprawnienia zwierzchnika służbowego odnośnie do pracowników urzędu gminy (Budzisz, 2019, s. 106-107).

Przechodząc na grunt pojęcia „polecenie służbowe”, należy wskazać, że mieści się ono w katalogu głównych uprawnień kierowniczych pracodawcy. Uprawnienia te sprowadzają się zasadniczo do możliwości bezpośredniego kształtowania procesu pracy poprzez formułowane w tym względzie nakazy, zakazy czy instrukcje, które z jednej strony odnoszą się do przydzielanych pracownikowi konkretnych zadań do wykonania, a z drugiej do udzielania wskazówek oraz wytycznych odnoszących się do procesu ich realizacji. Poprzez wydawanie poleceń służbowych dokonuje się konkretyzacji obowiązków pracownika. Poza prawem do wydawania poleceń służbowych pracodawca ma kompetencje do jednostronnego kształtowania treści stosunku pracy $\mathrm{w}$ ramach przewidzianych przez przepisy prawa pracy, jak również prawo ustalania świadczeń pracowniczych, ich rozmiaru oraz uprawnienia reglamentacyjne, a także dyscyplinarne. W powyższym znaczeniu za pomocą poleceń służbowych można jedynie, w granicach przewidzianych przepisami prawa, aktów wewnątrzzakładowych oraz umowy o pracę, kreować proces pracy pracownika, adresata polecenia. Polecenie służbowe nie może więc przykładowo jednostronnie kształtować bytu i treści stosunku pracy, rozstrzygać o świadczeniach z niego wynikających, jak również wkraczać w sferę uregulowaną przepisami prawa pracy. W powyższym kontekście należy przyjąć, iż przewodniczący rady gminy nie będzie uprawniony, by na podstawie art. 21a u.s.g. w szczególności nawiązać stosunek pracy z pracownikiem, rozwiązać go, postanawiać o wysokości wynagrodzenia czy podejmować decyzje w przedmiocie zasadności przyznania premii, nagród czy też nakładania kar porządkowych, jak również powierzyć pracownikowi na czas oznaczony wykonywanie innej pracy lub nakazać wykonywanie czynności pracowniczych w godzinach nadliczbowych (Gajewski, 2018).

Celem prawodawcy nie było to, aby przewodniczący rady mógł decydować o pracownikach w zakresie nawiązywania, rozwiązywania stosunku pracy czy w przedmiocie nagradzania i karania.

Przyznanie przez ustawodawcę przewodniczącemu rady gminy nowych uprawnień do wydawania poleceń służbowych pracownikom urzędu motywowane było tym, iż rada gminy jako organ samorządowy nie ma własnego aparatu admini- 
stracyjnego, który zapewniałby niezbędną pomoc w wykonywaniu jej zadań oraz kompetencji. W konsekwencji powyższego rada gminy polegać musi na wsparciu udzielanym przez urząd gminy, którego kierownikiem jest wójt (burmistrz, prezydent miasta). Niejednokrotnie rozwiązanie powyższe było niewystarczające, szczególnie w przypadkach różnic politycznych zaistniałych pomiędzy organem stanowiącym a wykonawczym, co w rezultacie mogło utrudniać prawidłowe wykonywanie zadań i kompetencji przez radę gminy (Gajewski, 2018).

Należy również wskazać, że w konsekwencji dokonanej zmiany przewodniczący rady gminy zyskał wśród radnych samorządu gminnego wyjątkową i szczególną pozycję prawną. Jest to istotne $\mathrm{z}$ uwagi na fakt, iż przewodniczący rady gminy nie jest odrębnym organem samorządu gminnego, można go uznać za organ wewnętrzny rady gminy. W doktrynie podkreśla się, że organami wewnętrznymi kierującymi pracami rady co do zasady są przewodniczący oraz wiceprzewodniczący rady gminy (Złakowski, 2011, s. 223). Pogląd, że przewodniczącego rady należy niewątpliwie uznać za organ wewnętrzny rady gminy, jest konsekwentnie podnoszony również w orzecznictwie (Wyrok NSA, 2007, II OSK 1456/07). Nie można uznać go za samodzielny organ gminy (Szmulik, 2012, s. 225), gdyż ustawodawca wyraźnie wskazał w art. 1la ust. 1 u.s.g., iż organami gminy są wyłącznie rada gminy oraz wójt (burmistrz, prezydent miasta).

Granice wydawanych pracownikom urzędu poleceń służbowych formułowanych przez przewodniczącego rady gminy wyznacza zakres kompetencji przewodniczącego rady gminy. A to z uwagi na fakt, iż ustawodawca w art. 21a u.s.g. zdanie pierwsze wskazał, że przewodniczący rady gminy może wydawać polecenia służbowe pracownikom w związku z realizacją swoich obowiązków.

Obowiązki przewodniczącego rady gminy przewiduje gminna ustawa samorządowa, jak i częstokroć statut danej jednostki samorządu terytorialnego oraz inne uchwały jej organu stanowiącego i kontrolnego pod warunkiem, że mieszczą się w zakresie wynikającym z art. 19 ust. 2 u.s.g. Zakres obowiązków przewodniczącego rady gminy określa więc w szczególności art. 19 ust. 2 u.s.g. Regulacja przepisu wskazuje, że zadaniem przewodniczącego rady gminy jest wyłącznie organizowanie prac rady i prowadzenie jej obrad. Podkreślenia wymaga jednak, że przepisy u.s.g. i innych ustaw przewidują ponadto wiele szczegółowych uprawnień i obowiązków przewodniczącego rady gminy, z których większość, jednakże nie wszystkie, mieści się w ramach wyznaczonych treścią art. 19 ust. 2 u.s.g.(Gajewski, 2018).

W doktrynie i orzecznictwie niezmiennie wskazuje się, że zadaniem przewodniczącego jest wyłącznie organizowanie pracy rady oraz prowadzenie obrad rady gminy. Użycie takiego określenia ma na celu dążenie do zapobieżenia ewentualnej ewolucji przewodniczącego rady w stronę pozycji ,trzeciego organu gminy” czy 
też organu o kierowniczych lub samodzielnych uprawnieniach w odniesieniu do rady gminy (Złakowski, 2011, s. 222). Przewodniczący może wyznaczyć do wykonywania swoich zadań wiceprzewodniczącego. W przypadku nieobecności przewodniczącego i niewyznaczenia wiceprzewodniczącego zgodnie z regulacją art. 19 ust. 2 u.s.g. zadania przewodniczącego wykonuje wiceprzewodniczący najstarszym wiekiem. Zadania przewodniczącego rady mają zatem charakter czynności materialno-technicznych. Przewodniczący nie ma więc uprawnień do reprezentowania gminy na zewnątrz, chyba że rada gminy działa wyjątkowo jako organ wykonawczy.

Dowodzi powyższego aktualne orzecznictwo sądowe. Jako przykład warto wskazać Wyrok Wojewódzkiego Sądu Administracyjnego w Poznaniu z dnia 7 listopada 2019 r. (Wyrok WSA w Poznaniu, 2019, IV SA/Po 674/19). W przedmiotowej sprawie sąd uznał za zasadne stwierdzenie nieważności uchwały przez wojewodę w zakresie, $\mathrm{w}$ jakim wyeliminowano z obrotu prawnego postanowienia statutu gminy naruszające regulację art. 19 ust. 2 u.s.g. poprzez nieprawidłowe rozszerzenie katalogu uprawnień przewodniczącego rady gminy, w sposób wykraczający poza przyznaną delegację ustawową. Naruszenia dokonano w zakresie, w jakim upoważniono przewodniczącego do reprezentowania rady na zewnątrz oraz ustanowiono możliwość upoważnienia $\mathrm{w}$ drodze uchwały innej niż przewodniczący osoby do reprezentowania rady na zewnątrz. Wojewoda wskazał, że w jego ocenie przewidziane w statucie gminy przedmiotowe uprawnienia dla przewodniczącego rady nie wynikają z art. 19 ust. 2 u.s.g., zgodnie z którym zadaniem przewodniczącego rady gminy jest wyłącznie organizowanie pracy rady oraz prowadzenie jej obrad, jak również stanowią nieprawidłową oraz nazbyt szeroką modyfikację regulacji ustawowej. Organ nadzoru wskazał, że zadania związane z pełnieniem funkcji przewodniczącego rady gminy wynikają wprost z u.s.g. oraz mają charakter materialno-techniczny. Koncentrują się one wyłącznie na organizowaniu pracy rady gminy, zwoływaniu i prowadzeniu jej obrad. Bez wątpienia, w przedmiotowym zakresie nie mieści się kompetencja przewodniczącego rady gminy do reprezentowania rady na zewnątrz ani osobiście, ani przez pełnomocnika. Uprawnienia przewodniczącego rady mogą być doprecyzowane w drodze postanowień statutowych, jednakże nie mogą wykraczać poza delegację ustawową. Sąd podzielił stanowisko wojewody w przedmiotowym zakresie i wywiódł, że ani art. 19 ust. 2 u.s.g., ani żaden inny przepis ustawowy nie stanowią podstawy do inkorporowania do statutu gminy regulacji przyznających przewodniczącemu rady gminy dodatkowych uprawnień do reprezentowania rady gminy na zewnętrz, a samemu organowi stanowiącemu kompetencji do upoważniania w tym zakresie innej osoby. Sąd podkreślił, że tego rodzaju unor- 
mowania wykraczają poza zakres materii statutowej również ze względu na fakt, iż ustalają zadania przewodniczącego - innej „upoważnionej” osoby - właśnie „na zewnątrz" administracji samorządowej, podczas gdy statut służy normowaniu jedynie wewnętrznego ustroju danej jednostki samorządu terytorialnego.

Podobnie w wyroku sądu administracyjnego (Wyrok WSA w Gliwicach, 2008, IV SA/Gl 396/08) wskazano, że zadania związane z pełnieniem funkcji przewodniczącego rady gminy wynikają z przepisu art. 19 i 20 u.s.g. i zostały ograniczone do organizowania pracy rady, w tym koordynowania prac komisji i działań klubów radnych oraz do zwoływania oraz prowadzenia jej obrad (sesji), w tym do decydowania o przedmiocie obrad rady, jak również do „dopilnowania, w jaki sposób uchwały rady są wykonywane" (Postanowienie WSA w Białymstoku, 2006, II SA/Bk 171/05).

Zadaniem przewodniczącego organu stanowiącego jest więc sprawne organizowanie oraz prowadzenie prac rady gminy, w tym przewodniczenie jej obradom. Czynności z zakresu organizowania prac rady gminy mają zasadniczo charakter techniczny oraz polegają w szczególności na przygotowywaniu projektu sesji, zawiadamianiu radnych o miejscu, terminie sesji oraz porządku obrad, przygotowaniu dla radnych stosownych dokumentów i innych materiałów, w tym również na odbieraniu skarg lub wniosków kierowanych do rady. Regulacja art. 19 ust. 2 kształtuje więc jasno „usługowy” charakter funkcji przewodniczącego w stosunku do rady gminy (Wyrok NSA, 2001, II SA 1525/00). W kontekście regulacji art. 19 ust. 2 u.s.g. nie ma podstaw do przyznania przewodniczącemu organu stanowiącego jakichkolwiek innych uprawnień, przykładowo w statucie gminy (Martysz, 2018, s. 351).

Przewodniczący rady wykonuje swoje zadania za pomocą biura rady lub innej komórki organizacyjnej wchodzącej w skład urzędu gminy. Należy jednak zaznaczyć, że nie ma on uprawnień do nadzorowania pracy tego biura, kierownikiem urzędu gminy jest bowiem wójt $i$ to jemu podlegają wszyscy zatrudnieni tam pracownicy, łącznie z tymi, którzy zajmują się obsługą rady gminy, jej przewodniczącego i komisji (Wyrok NSA, 1996, IV SA 695/96). Tym samym nie jest dopuszczalne utworzenie np. na potrzeby obsługi działalności rady kancelarii czy biura rady gminy jako odrębnego zakładu pracy podporządkowanego jej przewodniczącemu (Wyrok NSA, 1997, II SA 1885/96).

Powołany wyżej problem został również poruszony w orzecznictwie. Przykładem może być w szczególności postanowienie Wojewódzkiego Sądu Administracyjnego w Warszawie z dnia 28 marca 2019 r. Wprawdzie przedmiotowe orzeczenie z przyczyn formalnych nie rozstrzygnęło sprawy zawisłej przed sądem merytorycznie, jednakże prezentuje w uzasadnieniu obszerną analizę 
prawną dokonaną przez organ nadzoru w przedmiocie stwierdzenia nieważności uchwały rady miejskiej w zakresie, w jakim wprowadzono do statutu gminy regulacje stanowiące, iż obowiązkiem organu wykonawczego jest zapewnienie radzie obsługi organizacyjno-technicznej „niezbędnej do realizacji funkcji organu stanowiącego i kontrolnego Gminy, w tym przygotowywanie dokumentacji, wysyłkę korespondencji oraz udostępnianie wyposażonych w odpowiedni sprzęt biurowy pomieszczenia lub pomieszczeń do odbywania spotkań radnych z mieszkańcami Gminy oraz do odbywania spotkań i narad radnych". Istotne w niniejszej sprawie jest to, iż rada miejska argumentując zasadność swojego stanowiska, powołała się na treść art. 21a u.s.g., wywodząc, że przepis ten nadaje uprawnienia pracodawcy, przełożonego przewodniczącemu rady gminy wobec pracowników zatrudnionych w urzędzie miejskim, podczas gdy na mocy ustawy przysługują one wójtowi. Z tych też względów wprowadzenie zapisów technicznych w statucie, normujących tryb organizacji spotkan mieszkańców $\mathrm{w}$ urzędzie miejskim $\mathrm{z}$ radnymi, a więc $\mathrm{z}$ wykorzystaniem mienia urzędu oraz jego zasobów osobowych, jest jak najbardziej właściwe i zasadne. Z powyższym nie zgodził się jednak wojewoda, wskazując, że w jego ocenie powyższe zapisy aktu miejscowego są niezgodne $\mathrm{z}$ prawem $\mathrm{z}$ uwagi na fakt, iż brak jest do ich wydania jasnej i klarownej delegacji ustawowej, a żaden przepis u.s.g. nie daje podstaw do nakładania na organ wykonawczy wyżej opisanych obowiązków (Postanowienie WSA w Warszawie, 2019, II SA/Wa 161/19).

W kontekście powyższego dodanie do gminnej ustawy samorządowej art. 21a i wyposażenie przewodniczącego rady gminy w nowe kompetencje wskazane w tym przepisie zwiększa jego uprawnienia, począwszy od kadencji rad gmin wybranych w 2018 r., oraz ma doniosłe praktyczno-prawne znaczenie w kwestii organizacji pracy pracowników urzędu gminy. A to z uwagi na możliwość częstszego pojawiania się problemów z rozdzieleniem zwierzchnictwa służbowego między wójtem a przewodniczącym rady gminy, zwłaszcza w odniesieniu do pracowników szeroko pojętego „biura rady gminy”. W praktyce sytuacja ta może powodować niekiedy sytuacje konfliktowe, zwłaszcza w przypadku antagonizmów politycznych lub społecznych między przewodniczącym rady, jako organizatorem pracy rady, a wójtem jako kierownikiem urzędu gminy. Może to wpływać szczególnie negatywnie na pracę rady i jej komisji oraz funkcjonowanie urzędu. Ustawodawca przyznał bowiem przewodniczącemu rady prawo do wydawania poleceń służbowych pracownikom urzędu gminy wykonującym zadania organizacyjne, prawne oraz inne zadania związane z funkcjonowaniem rady gminy, komisji i radnych. Jest to katalog zadań dość szeroki i niezdefiniowany. Wynika jednak z tego, że przewodniczący rady nie może skorzystać z przysługujących mu uprawnień w jakiejkolwiek sprawie, ale 
tylko w zakresie ściśle związanym z jego kompetencjami jako organizatora pracy rady gminy, jej organów wewnętrznych oraz radnych. W pozostałym zakresie pracownicy komórek organizacyjnych obsługujących radę podlegają wójtowi jako kierownikowi urzędu gminy (Dolnicki, 2019, s. 100). Ustawodawca nie rozstrzyga, co w sytuacji, gdy pracownik otrzyma dwa sprzeczne ze sobą polecenia od wójta i przewodniczącego rady gminy, nie wskazuje, czy decydujące znaczenie ma mieć polecenie przewodniczącego czy pracodawcy $i$ jak $w$ takiej sytuacji winien zachować się pracownik oraz jakimi kryteriami się kierować.

Przedstawione powyżej wątpliwości potwierdza również stanowisko doktryny, gdyż w piśmiennictwie wskazuje się, że inkorporowane do u.s.g. w art. 21a rozwiązanie budzi szereg wątpliwości. Słusznie wskazuje Rafał Budzisz (2019, s. 107), że prawodawca nie rozstrzygnął problematyki swoistej dwuwładzy, mogącej skutkować wydaniem pracownikowi dwóch, sprzecznych ze sobą, poleceń przez kierownika urzędu oraz przewodniczącego organu stanowiącego. A to w szczególności z uwagi na fakt, iż ustawodawca utrzymał w mocy przepis statuujący wójta (burmistrza, prezydenta miasta) jako kierownika urzędu. Wskazuje się, że obecny kształt regulacji z pominięciem dokładniejszego sprecyzowania pozycji przewodniczącego rady gminy jako zwierzchnika służbowego wprowadza chaos organizacyjny wynikający z tego, że podmiot usytuowany na zewnątrz struktury urzędu gminy posiada możliwości ingerowania w pracę aparatu pomocniczego. Ponadto ustawa o pracownikach samorządowych nie wymienia przewodniczącego rady gminy jako pracownika urzędu. Odmiennie rzecz się ma w przypadku starosty czy marszałka województwa.

Również zgodnie z ustawą z dnia 26 czerwca 1974 r. - Kodeks pracy (art. 73 $\S 1)$ wybór przewodniczącego rady gminy nie stanowi podstawy do nawiązania z nim stosunku pracy (tekst jedn. Dz.U. 2020, poz. 1320 ). Analogicznie rzecz się ma w stosunku do pozostałych radnych. Zakaz pełnienia mandatu w ramach stosunku pracy dotyczy bowiem nie tylko przewodniczącego, ale i pozostałych radnych. Potwierdza powyższe orzecznictwo sądowoadministracyjne, zgodnie z którym ani przewodniczący rady gminy, ani jego zastępcy nie są organami gminy. Ich wybór nie stanowi także podstawy prawnej do nawiązania $\mathrm{z}$ nimi stosunku pracy (Wyrok NSA, 1990, SA/Ka 690/90).

Stosownie do powołanych wyżej rozwiązań przyjętych w u.s.g. zadaniem przewodniczącego rady gminy jest wyłącznie organizowanie pracy tego organu oraz prowadzenie obrad rady. Przedmiotowy zakres zadań wyznacza wobec powyższego granice, w jakich przewodniczący wykonuje uprawnienia zwierzchnika służbowego wobec pracowników urzędu gminy. Tego rodzaju sytuacja, odznaczająca się cechami istotnej nowości, wywołuje szereg obaw (Walczak, 2018, s. 17). 
Słusznie wskazuje Dawid Sześciło (2018), iż „Trudno więc będzie w sytuacjach spornych rozstrzygać, czy dane polecenie przewodniczącego mieści się w ustawowo dopuszczalnym zakresie. Ze względu na te wątpliwości w praktyce może się okazać, że rozwiązanie to będzie funkcjonowało w miarę sprawnie jedynie w samorządach, gdzie organ wykonawczy i przewodniczący rady (sejmiku) pochodzą z jednego środowiska politycznego i nie są ze sobą w konflikcie”. Warto podkreślić, że przepisy nie zawierają żadnych formalnych gwarancji egzekwowania wydanych przez przewodniczącego poleceń służbowych, co czyni przedmiotową instytucję mocno niedoskonałą.

\section{Wójt jako kierownik urzędu}

Jak wskazywałam na wstępie, tylko sprawne funkcjonowanie organów gminy może zapewnić prawidłową realizację jej zadań publicznych. Organ wykonawczy jednostki samorządu terytorialnego wykonuje swoje zadania dzięki odpowiednio zorganizowanemu aparatowi pomocniczemu - urzędowi gminy. Zgodnie z regulacją art. 33 u.s.g. wójt wykonuje zadania przy pomocy urzędu gminy, jest jego kierownikiem oraz pozostaje odpowiedzialny za organizację pracy w jednostce i ustala zasady funkcjonowania urzędu.

Wykładnia art. 33 u.s.g. może powodować szereg wątpliwości. W pierwszej kolejności wskazać należy, że przepisy prawa nie rozstrzygają, czy urząd gminy jest wyłącznie aparatem pomocniczym wójta, czy też może również rady gminy, jej organów wewnętrznych czy innych podmiotów. Bez wątpienia wójt jest organem wykonawczym gminy. Jest on obowiązany ponadto wykonywać uchwały rady gminy oraz inne zadania określone przez przepisy prawa, posiada również indywidualne kompetencje oraz jest kierownikiem urzędu gminy. Zaznaczyćjednakże należy, że pomimo powyższych wątpliwości urząd gminy faktycznie wykonuje również istotne zadania w zakresie obsługi rady gminy i jej wewnętrznych organów. Organizacyjno-techniczna obsługa tych podmiotów w strukturze urzędu gminy polega często w praktyce na wydzieleniu specjalnych biur lub stanowisk pracy. Pracownicy biura czy poszczególnych stanowisk indywidualnych są zatrudnieni w danym urzędzie gminy oraz pozostają podporządkowani na ogólnych zasadach wójtowi. Konkludując, wskazać można, że urzędy gmin stanowią nie tylko aparat pomocniczy wójtów. Pojęcie to ma charakter zbiorczy i obejmuje aparat pomocniczy także organów stanowiących gminy i ich organów wewnętrznych (Martysz, 2018, s. 589).

Kierownicza funkcja wójta gminy sprowadza się więc w szczególności do zapewnia efektywnego funkcjonowania urzędu i jest realizowana poprzez ko- 
ordynowanie pracy jego wewnętrznych komórek organizacyjnych, udzielania informacji o pracy urzędu czy też przyjmowania oraz rozpatrywania skargi i wniosków (Martysz, 2018, s. 593).

Konsekwencją kierowniczej funkcji wójta jest przede wszystkim hierarchiczne i służbowe podporządkowanie wszystkich pracowników urzędu wójtowi. W kompetencję tę nie wyposażono rady gminy, na co uwagę zwracają organy nadzorujące działalność gminy, w ich ocenie ustalenie zakresu obowiązków służbowych pracowników urzędu gminy oraz kierowników jednostek organizacyjnych gminy należy do wyłącznych uprawnień wójta gminy jako kierownika urzędu gminy, jakakolwiek zaś ingerencja w powyższym zakresie organu stanowiącego gminy narusza kompetencje wójta. Podporządkowanie hierarchiczne oznacza, że wszyscy pracownicy urzędu pośrednio lub bezpośrednio podlegają wójtowi oraz są obowiązani do wykonywania jego poleceń (Wierzbica, 2018, s. 598).

Ustawą, która określa status prawny pracowników samorządowych, jest regulacja z dnia 21 listopada 2008 r. o pracownikach samorządowych (teskt jedn. z dnia 14 czerwca 2019 r., Dz.U. 2019, poz. 1282), aktem wykonawczym do niej jest zaś rozporządzenie Rady Ministrów w sprawie wynagradzania pracowników samorządowych (tekst jedn. z dnia 15 maja 2018 r., Dz.U. 2018, poz. 936 z późn. $\mathrm{zm}$.), w pozostałym zakresie nieuregulowanym wyżej wymienionymi aktami odpowiednie zastosowanie znajdują przepisy Kodeksu pracy.

Wato wspomnieć, iż w konsekwencji dodania do u.s.g. art. 2la nie uległa zmianie wynikająca $\mathrm{z}$ art. 7 pkt 3 ustawy o pracownikach samorządowych zasada, zgodnie $\mathrm{z}$ którą czynności w sprawach z zakresu prawa pracy w stosunku do pracowników urzędu gminy wykonuje wójt. Realizowanie czynności w sprawach z zakresu prawa pracy jest formułą znacznie szerszą niż wydawanie poleceń służbowych w ściśle określonym zakresie. Wobec powyższego nie uległy modyfikacji podstawowe regulacje ustalone w ustawie o pracownikach samorządowych w zakresie, w jakim wyznaczają one osoby wykonujące czynności w sprawach z zakresu prawa pracy wobec pracowników urzędu gminy. Decyzje, w szczególności mające za przedmiot udzielenie urlopu, przyznanie nagrody, ukaranie, zmianę stanowiska, zmianę warunków wynagradzania, pozostają wyłączną kompetencją wójta (Walczak, 2018, s. 17).

Zgodnie z ustawą o pracownikach samorządowych przewodniczący rady gminy nie jest bezpośrednim przełożonym pracownika samorządowego, o którym mowa w art. 27 ust. 2 tej ustawy. Zgodnie z powołanym przepisem pracownik samorządowy zatrudniony na stanowisku urzędniczym, w tym kierowniczym stanowisku urzędniczym, podlega ocenie dokonywanej na piśmie przez bezpośredniego przełożonego. Jednakże z uwagi na fakt, że składową dokonywanej oceny 
jest w szczególności realizowanie przez pracownika obowiązków wynikających z zakresu czynności oraz wykonywanie poleceń przełożonego, należy postulować udział przewodniczącego rady gminy w procesie oceny (Walczak, 2018, s. 17).

Przewodniczący rady gminy kierując do pracownika polecenie służbowe, pozostające w związku z realizacją swoich obowiązków, wykonuje uprawnienia zwierzchnika służbowego w stosunku do pracownika. Dochodzi w ten sposób do dualizmu zwierzchnictwa służbowego, ponieważ kierownik urzędu nie traci swoich uprawnień na rzecz przewodniczącego, gdyż pozostaje nadal odpowiedzialny za sprawne funkcjonowanie aparatu pomocniczego, w tym również w zakresie zadań dotyczących obsługi rady gminy i jej komisji. Takie kumulowanie uprawnień w przedmiocie zwierzchnictwa służbowego w sposób najpełniejszy wyraża potrzebę współdziałania przewodniczącego i wójta gminy, żadnemu z tych podmiotów bowiem przepisy nie przyznają pierwszeństwa w zakresie realizacji kompetencji ani nie regulują usuwania ewentualnych konfliktów wynikających z wydania sprzecznych poleceń (Walczak, 2018, s. 17).

\section{Zakończenie}

Podsumowując, wskazać należy, że ocena nowelizacji dokonanej na mocy ustawy zmieniającej u.s.g. $z$ dnia 11 stycznia 2018 r. w przedmiocie dodania art. 21a do gminnej ustawy samorządowej nie jest w pełni zadowalająca. Zaproponowane przez ustawodawcę rozwiązania w przedmiocie wzmocnienia pozycji organu stanowiącego i kontrolnego, jak i w szczególności samego przewodniczącego rady gminy, choć w istocie miały pozytywny cel, to nie został on jednak finalnie osiągnięty. Po pierwsze możliwość wydawania poleceń służbowych, wskazanym w ustawie pracownikom urzędu przez przewodniczącego rady gminy, niejednokrotnie powoduje powstanie wewnętrznych konfliktów, szczególnie w relacji wójt jako kierownik urzędu - przełożony służbowy a przewodniczący rady jako realizujący uprawnienie $z$ art. 21a. u.s.g. Przykładowo rzecz taka ma miejsce w przypadku zaistnienia okoliczności, iż pracownik wykonując polecenie służbowe przewodniczącego rady gminy, świadczy pracę w godzinach nadliczbowych, co powoduje konieczność przyznania pracownikowi dodatkowego wynagrodzenia lub czasu wolnego wedle jego wyboru, który to obowiązek obciąża kierownika urzędu, niezlecającego faktycznie danej pracy. Kolejno prawodawca nie zdecydował również, polecenie którego z podmiotów ma prawo pierwszeństwa wykonania w sytuacji ich wzajemnej kolizji. Po wtóre nie wyposażył przewodniczącego rady w mechanizm pozwalający mu egzekwować wykonywanie formułowanych przez 
niego poleceń służbowych. Pracownikom zaś nie zapewnił stosownej ochrony przed negatywnymi konsekwencjami w przypadku realizowania poleceń przewodniczącego rady gminy, pozostających w jego kompetencji, których wykonania nie aprobuje kierownik urzędu. Ustawodawca nie usankcjonował również przypadków przekraczania uprawnień przez przewodniczącego zarówno w sensie podmiotowym (kierowanie przez przewodniczącego poleceń służbowych do pracowników spoza grupy wyróżnionej na podstawie kryterium wykonywanych zadań), jak i przedmiotowym (polecenia służbowe przewodniczącego rady gminy nie mogą dotyczyć ogółu zadań wykonywanych przez pracowników urzędu gminy ze wspomnianej grupy, lecz wyłącznie takich, które powiązane są bezpośrednio z zakresem obowiązków tego podmiotu). Regulacja pozostaje więc pod wieloma względami niedoskonała i wydaje się, że wymaga od ustawodawcy doprecyzowania celem usunięcia powyższych wątpliwości.

\section{Bibliografia}

\section{Akty Prawne}

Konstytucja Rzeczypospolitej Polskiej z 2.04.1997, Dz.U. 1997, nr 78, poz. 483. Pobrano z http://isap.sejm.gov.pl/isap.nsf/DocDetails.xsp?id=wdu19970780483 (10.05.2021).

Ustawa z 11.01.2018 o zmianie niektórych ustaw w celu zwiększenia udziału obywateli w procesie wybierania, funkcjonowania i kontrolowania niektórych organów publicznych, Dz.U. 2018, poz. 130. Pobrano z https://isap.sejm.gov.pl/isap.nsf/ DocDetails.xsp?id=WDU20180000130 (10.05.2021).

Ustawa z 21.11.2008 o pracownikach samorządowych, Dz.U. 2008, nr 223, poz. 1458. Pobrano $\mathrm{zhttp}: / /$ isap.sejm.gov.pl/isap.nsf/DocDetails.xsp?id=wdu20082231458 (10.05.2021).

Ustawa z 26.06.1974 - Kodeks pracy. Pobrano z http://isap.sejm.gov.pl/isap.nsf/DocDetails.xsp?id=WDU19740240141 (10.05.2021).

Ustawa z 8.03.1990 o samorządzie gminnym, Dz.U. 1990, nr 16, poz. 95. Pobrano z https:// isap.sejm.gov.pl/isap.nsf/DocDetails.xsp?id=WDU19900160095 (10.05.2021).

\section{Orzecznictwo}

Wyrok NSA z 12.09.1997 r., II SA 1885/96, Wspólnota 1998, nr 13, poz. 26.

Wyrok NSA z 17.01.2001 r., II SA 1525/00, LEX nr 54148.

Wyrok NSA z 21.11.1990 r., SA/Ka 690/90, ONSA 1990, z. 4, poz. 10.

Wyrok NSA z 26.06.1996 r., IV SA 695/96, Wokanda 1996, nr 12, poz. 46. 
Wyrok NSA z 6.12.2007 r., II OSK 1456/07, LEX nr 460513.

Postanowienie WSA w Warszawie z 28.03.2019 r., II SA/Wa 161/19, LEX nr 2771013.

Postanowienie WSA w Białymstoku z 11.04.2006, II SA/Bk 171/05, LEX nr 284731.

Wyrok WSA w Gliwicach z 3.11.2008 r., IV SA/Gl 396/08, LEX nr 509626.

Wyrok WSA w Poznaniu z 7.11. 2019 r., IV SA/Po 674/19, LEX nr 2741893.

\section{Literatura}

Augustyniak, M. (2020). W: M. Zdyb, J. Stelmasiak (red.). Prawo administracyjne. Część ogólna, ustrojowe prawo administracyjne, wybrane zagadnienia materialnego prawa administracyjnego (s. 443). Warszawa: Wolters Kluwer.

Budzisz, R. (2019). W: B. Dolnicki (red.), Pozycja ustrojowa organów jednostek samorządu terytorialnego (s. 102, 106-107). Warszawa: Wolters Kluwer.

Dolnicki, B. (red.). (2019). Samorzą terytorialny. Warszawa: Wolters Kluwer.

Gajewski, S. (2018). W: S. Gajewski, A. Jakubowski (red). Ustawa o samorządzie gminnym. Komentarz (Komentarz do art. 21a). Legalis.

Gurdek, M. (2008). Organy jednostek samorządu terytorialnego a organy administracji samorządowej. Przegląd Prawa Publicznego, 9, 61-76.

Martysz, Cz. (2018). W: B. Dolnicki (red.), Ustawa o samorządzie gminnym Komentarz (Komentarz do art. 19). Warszawa: Wolters Kluwer.

Martysz, Cz. (2018). W: B. Dolnicki (red.), Ustawa o samorządzie gminnym Komentarz (Komentarz do art. 33). Warszawa: Wolters Kluwer.

Sześciło, D. (2018). Nowe narzędzia dla obywateli i radnych w samorządzie. Opinia w sprawie ustawy $z 11$ stycznia 2018 roku o zmianie ustaw w celu zwiększenia udziału obywateli w procesie wybierania, funkcjonowania i kontrolowania niektórych organów publicznych ( $z$ wyłaczeniem zmian w prawie wyborczym), Warszawa. Pobrano z https://www.batory.org.pl/upload/files/Programy\%20operacyjne/Masz\%20 Glos/Opinia\%20prawna_Nowela\%20Kw\%20a\%20Samorzad\%20.pdf(10.05.2021).

Szmulik, B., Miaskowska-Daszkiewicz, K. (red.). (2012). W: Administracji publiczna: Komentarz, t. 3: Ustrój administracji samorządowej. Warszawa: C.H. BECK.

Walczak, P. (2018). Przewodniczacy rady gminy jako zwierzchnik służbowy pracowników urzędu gminy, Kontrola zarządcza w jednostkach sektora publicznego nr 10 (s. 17). Legalis.

Wierzbica, A. (2018). W: B. Dolnicki (red.). Ustawa o samorządzie gminnym Komentarz (Komentarz do art. 33). Warszawa: Wolters Kluwer.

Złakowski, Ł. (2011). W: R. Hauser, Z. Niewiadomski (red.). Ustawa o samorzadzie gminnym. Komentarz z odniesieniami do ustaw o samorządzie powiatowym i samorządzie województwa (Komentarz do art. 19). Warszawa: C.H. BECK. 


\section{Streszczenie}

Wraz z wejściem w życie przepisów ustawy z dnia 11 stycznia 2018 r. o zmianie niektórych ustaw w celu zwiększenia udziału obywateli w procesie wybierania, funkcjonowania i kontrolowania niektórych organów publicznych, przewodniczący rady gminy otrzymał nowe kompetencje. Kompetencje przewodniczącego rady gminy do wydawania poleceń służbowych pracownikom urzędu gminy ograniczają się do jego zadań związanych z organizacją pracy rady gminy, nie obejmując aktywności przewodniczącego organu stanowiącego i kontrolnego jako radnego. Przewodniczący rady gminy jest uprawniony wydawać polecenia służbowe pracownikom urzędu gminy wykonującym zadania organizacyjne, prawne oraz inne zadania związane $\mathrm{z}$ funkcjonowaniem organu stanowiącego, komisji i radnych. Zawarte w gminnej ustawie samorządowej sformułowanie, że przewodniczący rady gminy wykonuje uprawnienia zwierzchnika służbowego w stosunku do pracownika urzędu gminy należy odczytać w sposób ścisły, uwzględniając regulację art. 21a u.s.g.

SŁowA KLUCzowE: samorząd terytorialny, gmina, rada gminy, przewodniczący rady gminy, polecenie służbowe.

\section{Summary}

With the entry into force of the provisions of the Law of 11 January 2018 on amending certain laws to increase the participation of citizens in the process of election, operation and control of certain public bodies, the chairman of the municipal council received new powers. The competence of the chairman of the municipal council to give official instructions to the employees of the municipal office is limited to his tasks related to the organization of the work of the municipal council, not including the activity of the chairman of the establishing and controlling body as a councillor. The chairman of the municipal council is entitled to give official instructions to the employees of the municipal office performing organizational, legal and other tasks related to the functioning of the governing body, committees and councillors. The wording contained in the Municipal Self-Government Act that the chairman of the municipal council exercises the powers of an official superior in relation to the municipal office employee should be read strictly, taking into account the provisions of Article 21a of the Municipal Act.

KEYWORDS: local government, commune, commune council, chairman of the council, official order.

\section{Nota o autorze}

Sylwia Dąbrowska - mgr, doktorantka na Wydziale Prawa, Prawa Kanonicznego i Administracji Katolickiego Uniwersytetu Lubelskiego Jana Pawła II; działalność naukowa w dziedzinie nauki społeczne w dyscyplinie nauki prawne; e-mail: sylwia.anna.dabrowska@gmail.com; ORCID: 0000-0003-2888-527X. 